\title{
Myth and use of Mythology in Poetry of Islamic Revolution
}

\author{
Hojjatollah.ghe. Moniri'1, Nushin Dohniyatkar ${ }^{2}$ \\ ${ }^{1}$ Assistant Professor, Department of Literature, Islamic Azad University, Borujerd Branch, \\ Lorestan, Iran \\ ${ }^{2}$ M. A., Department of Literature, Islamic Azad University, Borujerd Branch, Lorestan, Iran
}

Received: 24 October 2018, Revised: 05 December 2018, Accepted: 20 December 2018

\section{ABSTRACT}

Mythology as one of imagination tools and also as one of the most significant elements of rhetoric has been used since the early usher of Persian poetry, though with its own ups and downs. Mythology has a different and significant role compared to previous ages especially during the first decade of Islamic Revolution (Sacred defense period). Since the analysis and investigation of this role has not been written yet, the present research tries to investigate and translate metaphoric roles through a simple and systematic design. In addition, it presents the position and statue of the poets who are in line with Islamic Revolution. In this paper, it is also shown that poets and orators of the period are not at the same level due to the experience, creativity, qualitative and quantitative efficiency of the myths. Some reach this level through recreating old patterns and integrating them with historical samples in a splendid language which is an integration of modern expression and Khorasani (a category of Urdu). Some others put a step forward and narrated some value symbols (abstract or conceptual) of their passionate history. Finally, a group of poets did not implement this magic element of imagination and their poetic symbols lack the visionary ambiguities of mythology.

Keywords: Mythology, Myth-Making, Poetry Of Islamic Revolution.

\section{Introduction}

Although various definitions have been suggested for Myth, the most comprehensive and widely used definition is: Myth is a kind of ancient ideology. Human beings' early attempts in knowing themselves and the world, their attempts to report about the world and people, has created an ideological school which is called myth (Kazazi, 1997). Myths, in fact, are not only byproducts of ancient men's thoughts about the universe and basic concepts of life, but they are directions for living based on them and can be a reason for society. Myths can also play the role of pieces of advice in an elegant moral collection and give human being some tips for people to live their lives based on them (Heynelz, 1992).

As it is known, myth is in some fields of study such as anthropology, theology, 
psychology, history and specifically Mythology. However, language is the element that relates myth to literature, of course a language in form of tokens and symbols not a simple and colloquial one. So, "metaphor", "symbol" and "myth" are called basic elements of rhetoric (Shafiei Kadkani, 1987).

Daiches says in this regard that:

"New efforts in the field of poetry naturally leads to research and investigation of symbols and metaphor in poetic language and opens a new field of research about myth" (ibid.)

Issue of myth in poetry, form some schools of contemporary literary criticism point of view, has a significant importance, especially those who criticize following Jung school of thought considering myth as their main field of research.

Based on Jung's point of view, myths is the unconscious expression and direct manifestation of a nation, which is called collective unconscious.

This collective unconscious keeps the racial background in it and it is the ne which creates primary heroes for different nations and also similar individual imagination for civilized people. ... Jung believes that artists and mental patients, restore the myths of primitive experiences' origin consciously or through imagination and dreams (ibid, 234-5).

Of course, it is obvious that comparing mental patients with "artist" - who does a knowledgeable and purposeful task by reviving and sometimes inventing myth is an erroneous analogy as professor Shafiee Kadkani also highlighted this part of Jung's:

"An artist is not a patient with neurological disorder, but, in fact, he as an artist is more important than a patient (ibid).

However, literature is the most talented and yet the most prominent art which has localized and visualized the legends. Myth, in literature, is presented in two ways : sometimes as a single and coherent narrative, such as myths and epics of Shahname- Firdausi( the epic dimension) and Mantegh al-Tayr of Attar (the mystical dimension), and sometimes has ornamental and spiritual aesthetic role and only some components of myth are used as symbols, such as some verses of Hafez, including this verse:

/Su:khtæm/ /dær/ /t $\Lambda \mathrm{h} /$ /sæbr/ /æz/ /bæhrə/ /ın/ / §æmə/ /tæægol/

/ $\Lambda \mathrm{h} /$ /turkın/ /færəğ/ /æz/ /hælə/ /mæ/ /ku:/ /rustæmi/

(Hafez, 1998)

\section{Discussion}

Beginning with the first dawn of classic Persian poetry, myths merged in light of literature, but Firdausi was the most significant rhetorician who employed myths in his poetry and art and called it his symbolic approach, as he said:

/to/ /In/ /rı/ /druğ/ /o/ /fəs $\Lambda$ nə/ /mæd $\Lambda$ /

/bə/ /rængə/ /fusun/ /o/ /bæhınə/ $/ \operatorname{mæd} \Lambda \mathrm{n} /$

/az/ /vo/ /hær/ /te/ /ændær/ /

(Ferdowsi, 1966).

From Firdausi till the middle of the sixth century, the poets used old archetypes and myths but since then, with the advent of the famous poets like Attar and Rumi, sparks of brilliance of new myth and over constructed started and reaches its peaks in the eighth century with Hafiz. Myth-making heydays in classical Persian poetry- even in its modern definition- must be seen in pieces of Hafez:

Speech and stories of Hafez are different from the world outside not opposed to it, but it is a more idealistic, exemplifying and eternal. Myths of Hafez 
do not refer to Iranian mythology (Jamshid, Keykavousi, Afrasiab, Syavash and so on), or to historical figures (such as Bahram Gur and Alexander) or Quran stories (like Adam, Solomon, Elias, Moses, Jesus and Joseph). It means that it exists in these but these are not created and added by Hafez character but Hafez is the heir of them. However, his real myths are based on his own nature and if they are taken from other cultures and myths as incomplete symbols, such as wine, magi and slicker and pub, he has changed it into a perfect myth .... And in one word, Hafez makes myths out of life and all its symbols and we see a more colorful, happy life through magic prism of his poetry and get free from our sadness and worries and see our dreams could come true (Khoramshahi, 2002).

Since the history of Hafez then, even in long life of Indian style and in spite of some exquisite poets who are meticulous and create concepts like Bidel, Kalim and Saeb- nobody, except recently some modern poets like Nima, Akhavan and Shamloo, could emerge as an outstanding poets to make innovation out of myth. In present century, myths have been revived and different forms of them - which some have been unknown until recently and inevitably out of reach- emerged in widespread literary (poetry and prose).

As we know, tendency toward symbols (and accordingly myths) is sometimes optional in literature (enriching the piece) and sometime mandatory and inevitable (out of censorship) (Mirsadeghi, 2001).

Modern poetic and literary trend had no reason except making Iranian poets and authors acquainted with world literature and influence of schools such as symbolism and surrealism, and also making a powerful hegemony of internal dictatorship and its accompanied political thoughts.
Before Islamic Revolution, dependence and attachment to symbols and symbolism in poetry was more influenced by political atmosphere of the country not by speech array and empowerment. However, after that and among the poets of revolution, paying attention to symbol and myth was not a matter of political necessity but also deepening the meaning and empowering the mental aspect of speech which by occurrence of war and calendaring the fire of patriarchic and national sense, became more and more interesting.

If we want to picture the myths of revolution in a clear, helpful and available framework, following framework can be a proper pattern for showing the ways of benefiting from myth and its species: 1) semantic and theme myths, 2)pre-historic and historic myths, 3) conceptual and abstract myths.

\section{Semantic and Theme Myths}

Semantic myths are defined as myths which refer to meaning and theme; meanings such as nationality, race, religion, mystics, time and location.

Emergence of Islamic Revolution- and a little later, imposed war and attachment to a period called sacred defense in which epic, love and mystics combine togetherprovide an exceptional situation for poets of revolution to use semantic myths, so that stories of Shahname and Quransuddenly revived and its epic elements become a spiritual source of many pieces and songs of those who were generation of revolution. Semantic myths- by itself- can be studied in four major categories:

A: National and heroic myths: poets of revolution, with a different view of previous periods about Shahname- this great culture of story and myth- and benefitting from speech style of Firdausi's have put rhetoric and myth elements (positive and negative) against historical 
models of modern time and in addition to deepening the aforementioned models, have employed elements and components of mythology in metaphoric and secondary meanings with these analogies.

Following is the literary piece of Hamid Sabzevari which expresses sorrow about losses of revolution youth in sacred war period and wishes that doers would never take the power:

/zə/ /fətnə/ /sızi:/ /gærsiuzınə/ /ku:n/ $/ \Lambda \int \Lambda \mathrm{m} /$

/æzム/ /gərəftə/ /dəlæm/ /dær/ /ğæmə/ /si:ævu: $\{\Lambda \mathrm{n} /$

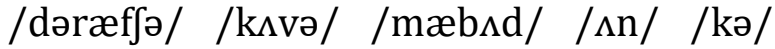
/bær/ /zæmi:n/ /oftæd/

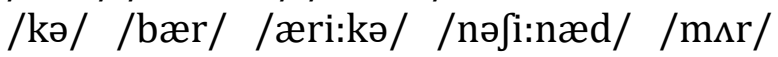
/bær/ /du: $\int \Lambda \mathrm{n} /$

(Sabzevari, 2010)

In this line, Mohammad Ali Moalem depicts a statue which is symbol of America and calls this emperor of the present century as a Hecate who has gained her obesity and corpulence from historical lands like Iran and her glory is all fake and loan:

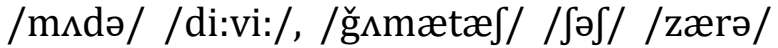
/o/ /si:sæd/ /pai/- /tji:zi:/ /kæm/

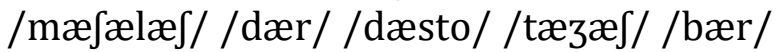
/sær/ /æz/ /tırızə/ /molkə/ /3æm/

(Moalem, 2010)

Abdul Jabar Kakaiee, with a wider view, considers myth as a mirror of history and covered all historical events with myth and changed the myth into reality:

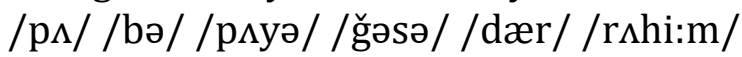

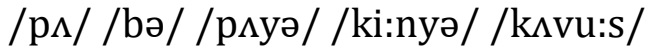

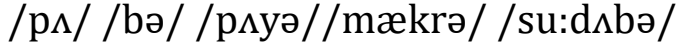
/bær/ /səti:ğə/ /ku:h/ /toun/ / $\mathrm{rr} / /$

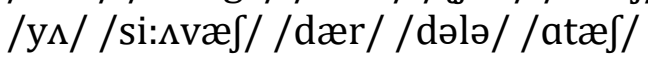

(Kakaiee, 2008)

Some other poets, totally got out of epic mythology and symbolized the myth in a different area and context. For example
Mohammad Ali Bahmani with this emotional and romantic content: /gerd/ /ufæri:d/ /tu/ /fæğæt/ /æz/ /æsbæ// /u:ft $\Lambda \mathrm{d} /$

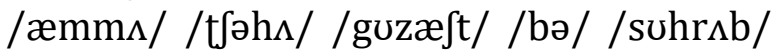
/ğælə//gi:r/

(Bahmani, 2011)

Or Seyyed Hassan Hosseini with an irony: ... /dær/ / əəgəfæ/b $\Lambda \int /$

/æz/ /i:n/ /hæmısəуә/ /t\}uru:k/ /khurdə/

/æz/ /rustæmi:/ /kə/ /əynækæJ/ /rı/ /gufə/ /dımænæt/ /3ムmə/ /3æm/ /mi:kunæd/

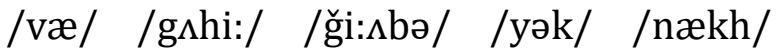
/si:gnr/

/t\}un/ /huzurə/ /di:və/ /sepi:d/

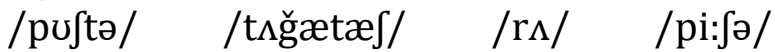
/t〕æmhıуә/ /harræt/ /zædəæt/ /khæm/ /mi:kunæd/ !

(Hosseini, 2009)

In addition, presence of myth and epic elements in order to construct moral and mystic meaning has been an interested way among some poets of revolution:

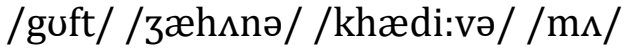

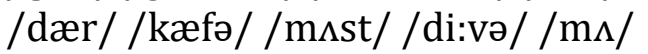
/mındə/ / tərı/ /bə/ /khınə/ /ğæm/

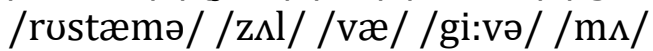
(Moalem, 2010)

B. religious and theological myth: after national and ancient myth, religious and theological elements (prophets, leaders and saints) are among many characters which poets of revolution always benefited from them as mythological elements. These "myth schemata" have an equal role in creating epic-revolutionary compared to national and ancient myth and has a more significant role in poems of others such as Gheysar Aminpour, Abdul Jabar Kakaiee, and Fatima Rakeiee. 
Such as myths of Ibrahim (PBUH) and Solomon (PBUH):

/Æz/ /rıh/ /rəsi:dəi:m/

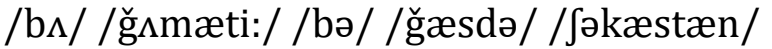
/lıt/ /o/ /mæm $\Lambda / / \mathrm{r} \Lambda /$ /kə/ /Jəkæsti:m/

/æzzD:/ /dəgær/ /æzi:z/ /nəmi:mınæd/ .

..

/æz/ /rıh/ /rəsi:dəi:m/

/mi:rısə/ /bıstıni:ə/ /ebrıhi:m/

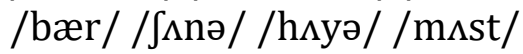

(Aminpour, 2011, p.373)

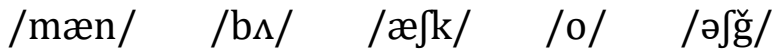

/mi:nəvi:sæm/

/Saər/ /mæn/ /ţun/ /mu:r/

/bær/ /kığæz/ /rıh/ /uftıdə/ /æst/

/soleymın/ /vır/

/bə/ /ni:m/ /negshi:/ /bær/ /mæn/ /dəræng/ /kun/

(Garmaroudi, 2011)

Sometimes, poets create semantic harmony by integrating and combining old ancient myths with religious and historical models and present a soul in two bodies. Such as Zolfaghar and Rakhsh in this poem:

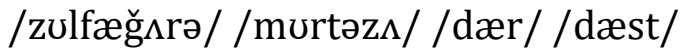

/bi:/ /æm $\Lambda$ / /pı/ /dær/ /rəkıbə/ /rækhf/

/æz/ /kævi:r/ /væ/ /ku:h/

/dær/ /pænıhə/ /rækhJ/ /æz/ /kævi:r/ /o/ /ku:h/

/dær/ /pænıhə/ /sıye/ /sırə/ /nækhl/ /o/ /gerdu:/

/gærmə/ /peykıri:m/

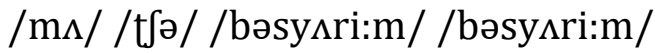

(Kakaiee, 2009)

C. Mystic Myths: mystic myths are either created out of poets and orators' imagination of past, such as symbols of Mantegh-al-teyr of Attar (Simurgh, simurgh, hoopoe, Gaf, ...) or historical models which are called by myths ( such as Halaj, Shams-e-tabrizi, Molana, Shekhe Eshragh, ...)
Moallem has symbolized the late leader of revolution as a hoopoe which guides his people toward ideals of Revolution or God: /zəbri:lə/ /næfsə/ /khud/ /ni:st/ /hudhud/ /sæfi:rə/ /ğ $\Lambda f$ / /æst/ /ræhbær/ /kə/ /ræh/ / Jənısæd/ /sılırə/ /bi:/ /khælıf/ /æst/

(Moallem, 2010)

And Mohamad Ali Bahmani refers to his own story by illusion of Hallaj:

/Rəsi:dəæm/ /bə/ /kæmıl/ /kə/ /juz/ /ænæl/ /hæğ/ /ni:st/

/kæmıldır/ /bærıyə/ /mæn/ /kæmıl/ /pæræst/

(Bahmani, 2011)

And finally Gheysar Aminpour with his own gifted taste chooses "Sheykh-eeshragh" and "Aghl-e-sorkh" (with some amphibology) out of mystic attributes:

/fæb/ /kıfær/ /furu:/ /Jud/ /dær/ /si:shi:/

/bə/ /æğlə/ /surkh/ /sær/ /zæd/

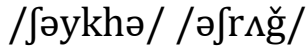

(Aminpour, 2011)

D. Place and Space Myths: space and place elements are concluded in reach of semantic myths, too. Places and spaces are sometimes completely legendary or sometimes historical and real. Some legendary places include: Touran, Samangan, Alvand mount or Qaf mount and when historical places- like any other time- are created in poet's mind in a supernatural and holy aspect, play the role of place and legendary symbols. Place myths such as "Hovize" and "Karbala" are mentioned in this line:

/Рæултә/ /dæftə/ /huvəуzə/ /bə/ /kærbælı/ /guyæd/

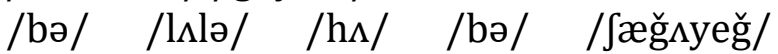

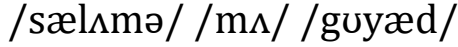

(Sabzevari, 2009) 
Or "Baghie”, "Al-khalil”, "Qods", “Om-alQora" and "Abu Qeys" in this poem:

... /bær/ /mi:gærdæm/

/ru:hæm/ /rı/ /dær/ /su:sæni:/ /səpi:d/ /bəpi:tðæm/

/kə/ /nıgəhın/

/dərækht/ /hıуə/ /khi:ıbın/ /bə/

/suzdə//mi:oftæd/!

/tufæni:/ /az/ /bæği:/ /mi:ıyæd/

/æz/ /mæszədə/ /um/ /æl/ /ğurs/

/æz/ /pæyə/ /ku:hə/ /æbu/ /ğəys/

/dərækht/ /h^yə/ /khi:^bın/ /bə/

/gəryə/ /mi:oftænd/

/mæn/ ni:z/

/khıhæm/ /geri:st/

/bırınə/ / $\varepsilon \mathrm{r} / / \mathrm{mi}:$ bæræd/

/væ/ /pəlk/ /vızəhıyæm/

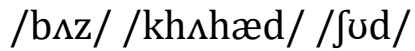

(Ghazve, 2006)

And we can mention " $/ \Lambda$ ğ $\Lambda$ z/" (beginning),

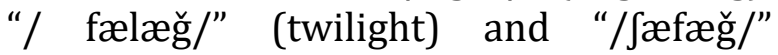
(crepuscle) here:

/mi:rævæm/ / / /kunæm/

/dær/ /dələ/ /ai:nə/ /zai:/ /vı/ /kunæm/

(Begigi Habib Abadi, 2009)

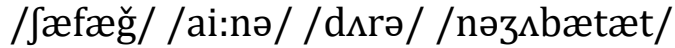

/væ/ /fælæğ/ /məhrıbi:/ /kə/ /tu/ /dær/ $/ \Lambda \mathrm{n} /$

/næmızə/ /subh/ / æhıdæt/ /guzırdəi:/

(Garmaroudi, 2011)

\section{Historic and Prehistoric Myths}

Prehistoric myths are the ancient and real myths which form the mental seepage and beliefs of ancient and prehistoric people. Historical myth means real events and their related elements which have conceptual aspects and in a period of human history has changed into reality.

However, is a poet allowed to limit the history by myth? Some literary scholars answer that by considering the conceptual extension of myths, poets not only has the choice, but in fact is inevitable to do it (Shafiee Kadkaniee, 1984)

And some others based on believing unity of the universe and human being in nature as one of the basic principles of myth, considered "personification" based on this ancient belief and said:

Personification or ironic metaphor in literary domain, has completely reminded of mythological ideology and it seems that it is not poetic to be created out of poet's mind. This type of literary usage which reflects ancient beliefs, should be investigated from ideology and semiotics view, not from aesthetic aspect (Kazazi, 1997)

And finally it is concluded that:

Myth maker human beings (primitives), in fact, do not differ from modern poets. Both of them live among the objects of life and both deal with them ... so, although the poet changes based on his condition and environment, changes his face and clothing style, but since he lives between eternity and primitivism do emotions and instincts, he is always a myth maker, because his imagination power has been accompanying him all the time and objects has been around him (Barahani, 1992).

However, poet of Revolution is well aware of the leverage of the myth and legendary symbols in meanings of poetry, so he can use this magic element and narrates his own time which is exceptionally critical from historical perspective.

One of the interesting literary styles in this period of time is to compare the historical symbols to ancient and prehistoric ones, beside confirming and enhancing the real and historical aspect. As it can be seen here:

/fəsınə/ /gæft/ /o/ /kuhæn/ /уıdə/ /rustæmə/ /dæstæn/

/æz/ / nn/ /hæmısə/ /kə/ /bı/ /khun/ /suru:d/ /khuzəstın/ 
(Sabzevari, 2009)

/kırə/ /musləm/ /æz/ /si:avusın/ /zod $\Lambda$ st/

/rıhə/ /hæğ/ /æz/ /rıhə/ /turkəstın/ /zudæst/

/ın/ /bə/ /p^ki:/ /3^nə/ /khud/ /dær/ /mi:bæræd/

/i:n/ /bə/ /kuyə/ /dəlbæræn/ /sær/ /mi:bæræd/

/ın/ /yəki:/ /suod $\Lambda /$ /bə/ /p $\Lambda$ ki:/ /bær/ /næhıd/

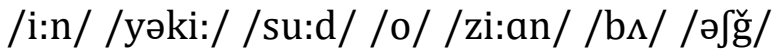
$/ \mathrm{d} \Lambda \mathrm{d} /$

(Garmaroudi, 2011)

It should be mentioned that, these types of comparisons in poetry of Revolution, as can be found in poems of Ghaznavi and Slajoghi period such as in poems of Amiri Moazi, is not aimed at belittling the national and ancient myths. But (based on simile and preferring simile to similarity), it is one of the literary tricks.

However, in these types of comparisons, national mythological elements do not always play the role of the second part of a simile, but sometimes mystic and natural myths are the choice of similarity for the poet. For example, the myths of /ğuğnu:s/ (Phoenix) and / $æ$ æhi:d bəhəfti:/ (Martyr Beheshti) in this line:

/hædi:sə/ /kuhnəyə/ /ğuğnu:s/ /zəndə/ /æz/ /v/ / Sud/

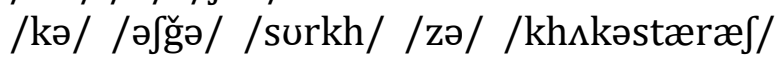
/zæbınə/ /gərəft/

(Rakaiee, 2007)

Or calling "sun" (/khurfi:d/) flares compared to the glance of mighty leader of Revolution:

/bıyæd/ /bə/ /3цуә/ /nærgəs/ /о/ /mæsti:/ /bi:ıværæm/

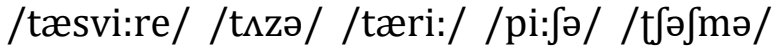
$/ \mathrm{to} /$

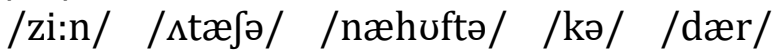
/si:nәуə/ /mæn/ /æst/ /khurfi:d/ /fulə/ . . . /næ/, /færæri:/

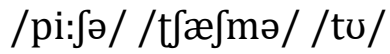

(Aminpour, 2011)

\section{Constructed and Pre-Constructed Myths}

Myth can be defined as constructed and pre-constructed in terms of creativity and innovation. In fact, the position of poet and his artistic role are mostly recognized under these two categories:

By the beginning of each century, new objects would enter the language and poetry and poet and owner of the time, justifies his own emotions and thoughts compared to new objects. But the objects which are in the era of language and poetry are not considered as outcast, especially those which are related to the existence of nature. Modern poet determines his own role about the objects of pervious poets. So it can be easily seen that how a "tree" which has been mentioned in many poems before, can be seen again and with that same point of view fix the special time and location. It can also be seen that how in modern age, we can symbolize or personify a tree. We must believe that every generation can make its own myths and grow and leave it (Barahani, 1992).

So, quality and quantity of every generation's myths fit with two things: cultural, social and political environment of a poet's life and the amount of a generation's artists' creativity. In poetry of Revolution, both type of myth constructed and pre-constructed- have many examples. It must be said that these types can be further divided into two more categories called shared or collective myths and personal or specific myths. In poems of Revolution, some objects and words- suddenly and synergic- has been taken into account and each of the poets have their own role in growing the objects and words and enrich them with myths 
and mythological items. Such as myths of "city" (/ æhr/) in this blank lyric:

/kærkæsh $\Lambda$ /

/yək/ /læhzə/

/tə̧һrə/ / $\Lambda \mathrm{ft} \Lambda \mathrm{b} / / \mathrm{r} \Lambda / / \mathrm{mi}: \mathrm{pu}: \int \Lambda$ næd/

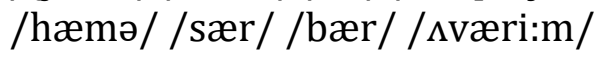

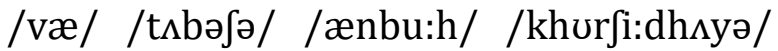

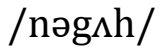

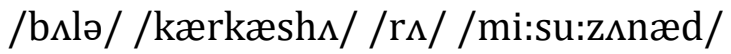

/væ/ /dubırə/ / $\Lambda \mathrm{ft} \Lambda \mathrm{b} /$ /mi:\{ævæd/

/væ/ / /æhr/ /həzır/ /khurfi:d/

/læbkhænd/ /mi:zænæd/

/væğti:/ /lıjkhurın/ /æz/ /du:rtæri:n/

/ğ $\Lambda$ / /tærs/

/dær/ /asəm $\Lambda$ / /pəyd $\Lambda$ / /mi:Javand/

/væ/ /fæzlə/ /hıуә/ /zæhrıgi:n/

/bə/ /dımınə/ / §æhr/ /mi:æfkænæd/

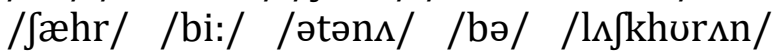

/væ/ /zı̆̆ $\Lambda$ n/

/d $\Lambda$ mænə/ /khud/ /rı/ /mi:tækınæd/

(Garmaroudi, 2010)

Or "red" /Surkh/ and "green" (/sæbz/) myths in this sonnet:

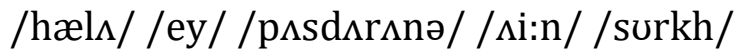

/sævırınə//furi:də//bær//zi:nə/

/surkh/

/bə/ / fərə/ /dæli:ri/ /tæsıvi:rə/ /sæbz/

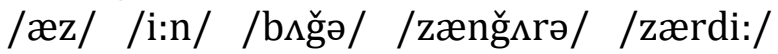
/zədu:d/

/væf $\mathrm{t} \Lambda \mathrm{n} /$ /bə/ /æhdə/ /di:ri:nə/

/surkh/...

(Hosseini, 2012)

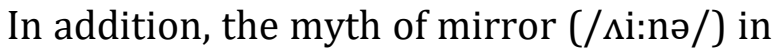
following sonnet:

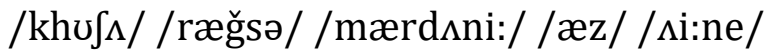

/sævırınə/ /məydıni:/ /æz/ / $\mathbf{\text { ine/ }}$

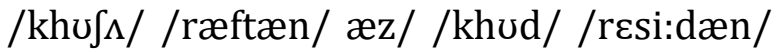

/bə/ /khi:f/

/sæfær/ /dær/ /khi:ıbıni:/ /æz/ / $\Lambda$ i:ne/

(Aminpour, 2011)

We can also point to more examples of generation and most frequent myths of Revolution as follows: water, rain, waterfalls, tulips, cedar, rider, sun, nightingale, sun, moon, people (nation), Imam, Martyr Beheshti and ...

But constructed myths and personal ones in poems of Revolution cannot be mentioned a lot. However, sometimes there are myths which are completely personal and are grown in mind of a poet. Such as myths of "rider" and "dawn" in poems of Sabzevari, "star" in poems of Moallem, "ocean" in poems of Garmaroudi, "silence' in poems of Hosseini, "sunflower' in poems of Gheysar Aminpour, "Train of Andimeshk" in Qazve, "tree" in Abdulmalekian poems, etc. However, present author prefers to use some personal myths of interest for some poets of Revloution from their own writings:

I belong to a national and religious mythology and I always see them together, as can be seen in the poem "a lot" (/t /bəsi: rr/). But "Lanthorn" (/fınu:s/) in my poetry is a special symbol - a myth. For me, this means an opening toward light. Lanthorn has been particularly interesting to me which is related to the memories of my childhood. At that time, we lived in the village with my mother and we had to go a long distance to town and go to the school. So, I always had a lanthorn with myself (an interview with Abdul Jabar Kakaiee, 2012).

I always liked someone to analyze my poems from mythological and symbolic point of view. Myths in my poems are Zahra (PBUH), Zeynab (PBUH), Salman, Abuzar, ... even Beheshti. In my poems, Beheshti is considered as a myth (Interview with Rakaiee, 2012)

I'm interested in Arash and Seyavash. As you know, I am a military man. I've been both in front and in poetry of war. I think all the fighters are legends: Hemmat, Chamran, Sayadshirazy and others.

D. Conceptual and Abstract myths:

Myth can be divided into two categories of conceptual and abstract in terms of 
being tangible or intangible. Paying attention to conceptuality of the myth is not task of a modern poet and we can find some signs of it in literary pieces of past. For example, "sadness" and "love" in following poem by Hafez:

/nısəhæm/ /guft/ /kə/ /3uz/ /ğæm/ /t〕/ /hunær/ /d $\Lambda$ ræd/ /əJğ/?

/buru/ /әı/ /kh^zə/ /ağəl/, /hunæri:/ /bəhtær/ /æz/ /i:n/

(Hafez, 1998 p. 313)

But in modern poetry and following that in poetry of Revolution, poets have more conscious and aware tendency toward abstract and intangible myths. Some of abstract myths are extraordinary and out of human nature and behavior. For example, "beginning" $\left(/ \Lambda \mathrm{g}_{\Lambda} \mathrm{z} / \mathrm{)}\right.$ in this line:

/mi:rævæm/ / $\Lambda$ ğ $\Lambda \mathrm{z} / \mathrm{r} \Lambda /$ /pәyd $\Lambda /$ /kunæm/

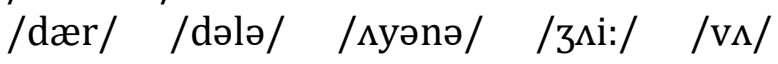
/kunæm/

(Beigi habib abadi, 2009)

And some others are included in moral aspects (general or specific) such as : "sleeping" (/khuftæn/), “ awakening" (/bi:dıri:/) , “ excitement” (/Jurængi:zi:/) and other in this poem :

/ey/ /khuftænə/ /gær $\Lambda$ sbə/ /tu/

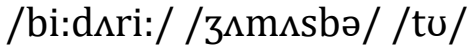

/bu:d $\Lambda$ / / Jurængi:z/ /tu/

/ey/ /khunəæt/ /f $\Lambda \mathrm{r} \Lambda \mathrm{b} /$ /o/ /vın/

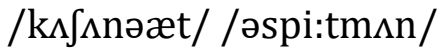

/zærtuft/ /bælkhu/ /fi:zə//tu/ ...

(Moallem, 2010)

And "heart", "humility" and "pride" in this poem:

/fævırei:/ /zə/ /nu:r/ /bəkıri:d/

/ğælbi:/ /æz/ /ıi:nə/, /dəli:/ /æz/

/dæri: $\Lambda$ /

/væ/ /gærdæni:/ /bulænd/

/æz/ / $\mathrm{b} \int \Lambda \mathrm{r} \Lambda \mathrm{n} \partial / / \mathrm{p} \Lambda \mathrm{k} / / \mathrm{tæv} \Lambda \mathrm{zv} /$

/yæ/ /æz/ /ğru:rə/ /mæhz/ /bəsızi:d/

(Aminpour, 2011)

\section{Conclusion}

The role of myths in enhancing imagination and providing poetical space in modern era is attractive and powerful. However, in the poetry of Revolution, this role is quite different. Poets of Revolution, mostly from this generation, are influenced by ideology of that time. These orators are a lot in number but a few of them are real representatives of legendary poets of exciting history of revolution. Among them, some revived the ancient and religious legends and combined them with historical symbols of revolution and connected yesterday and today. Finally, some also used symbols and cliché myths for deepening the meaning.

\section{Footnote}

In poetry of this poet, we can find a lot of ancient legends which has been belittled and Firdausi himself has been reproved due to collecting archetypes of legends. For example:

/ggam/ /fərdərd:/ /bə/ / /ə / /ərdr to

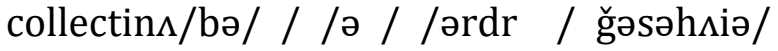
/pur/ /æзАуәb/, /fæthıуә/ /pur/ /pmr/ /mæn/ /æzæb/ /dæræm/ /zə/ /fع:rdusi:/

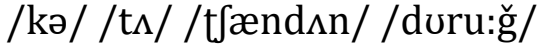

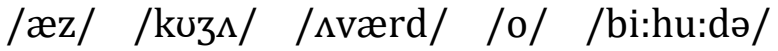
/tər $\Lambda /$ /guft/ / $\Lambda \mathrm{n} /$ /sæhær/

/gærtð//ou:/ /rustæm/ /guftə/ /æst/ /bəsi:ıri:/ /duru:ğ/

/guftə/ /ms/ /rıst/ /æst/ /æz/

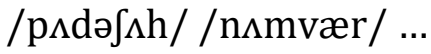

(Moazi, 1934)

\section{References}

Aminpoor. Gh. (2011). Complete collection of poems, 6 puplished, Tehran: Pearl.

Baraheni. R. (1992) Gold in copper, 1 version, Tehran: Author.

Baraheni, M. A. (2011). Poems collection, Tehran: Negah. 
Beigi Habibabadi, P. (1388). Chapter III, ch 3, Tehran: Theca.

Hafez. (1998). Court of correction, Qazwini -rich (with an introduction by Pejman Bakhtiari), Tehran: Parsa.

Khoramshahi. B. (1987). Hafiznameh. Scientific and cultural Journal, Tehran.

Hosseini, S. H. (2009). The kingdom of silence, Iranian poets, Tehran.

Hosseini, S. H. (2012). With The sound of Ishmael. Published in Tehran: Chapter October.

Raky, F. (2007). Yesterday, there was someone with us. Tehran: Ascension.

Sabzevari, H. (2010). Another song. Iranian Pen Association

Sabzevari, H. (2009). Dawn Song. Iranian Pen Association

Shafee Kadkani, M. (1987). Imagery of Persian poetry. Iranian Pen Association.

Abdolmalekian, M. R. (2011). The world has back to its pigeon, Tehran: Pearl.
Firdausi. (1966). Shahname. Bertls, Moscow.

Qazveh, A. (2006). Poldokhtar Train. Golden Disc, Tehran.

Kakaee, A. (2008). Silence by talking, Tehran: Science.

Kazazi, M. (1998). Dreams, Epic, Myth. Tehran Center, $2^{\text {nd }}$ edition.

Moezi, A. (1934). Correction of Abbas Iqbal, Islamie.

Moallem Damghani, M. (2010). Torn voice is in the Wind. Tehran

Mousavi Garmaroodi, A. (2010). Olive on the branch of bergamot, Tehran.

Mousavi Garmaroodi, A. (2011). Ear ring of Throne. Tehran.

Mirsadeghi, J. (2011). Story of Elements. Tehran Words.

Heynelz, J. (1992) Recognition of Iranian mythology, translated by Moallem, J. \& A. Tafazzoli. Tehran Springs.

How to cite this article: Hojjatollah.ghe. Moniri, Nushin Dohniyatkar, Myth and use of Mythology in Poetry of Islamic Revolution. International Journal of Advanced Studies in Humanities and Social Science, 2019, 8(2), 148-157. http://www.ijashssjournal.com/article 84353.html 